\title{
CER1 Gene
}

National Cancer Institute

\section{Source}

National Cancer Institute. CER1 Gene. NCI Thesaurus. Code C95062.

This gene may be involved in both gastrulation and neural development. 